\title{
A KELET-DUNÁNTÚL AVAR KORI NÉPESSÉGVÁLTOZÁSAINAK TÖRTÉNETI EMBERTANI VIZSGÁLATA
}

\author{
Szeniczey Tamás \\ Eötvös Loránd Tudományegyetem, Embertani Tanszék, Budapest \\ Témavezetö: Dr. Hajdu Tamás
}

Szeniczey T.: Biological reconstruction of the Avar Period population changes in EasternTransdanubia. During the Early Avar period, the Eastern-Transdanubian part of the Carpathian Basin was characterized by cultural heterogeneity. Beside the late antique and Germanic cultural elements the byzantine goods as well as the steppe traditions were included in the archaeological material of this period. The multicultural milieu completely disappeared by the beginning of the Late Avar Period that was defined by a much more standardized culture. In the light of the cultural changes, could we assume that the bearers of the antique and Germanic culture of the Early Avar period are the descendants of the former Romance and Lombard groups? If so, what happened to this populations during the Avar Period, how did they interact with the steppe-originated Avars? Was the Late Avar acculturation caused by new immigrants or is it solely a cultural integration? Based on the results of my dissertation, the continuity of the late antique and Germanic groups to the Early Avar period has been proved. The cultural influences and relations of these local populations contributed to the emergence of the Early Avar material culture of Eastern-Transdanubia. The Early Avar period males of other regions had little biological impact on the Eastern-Transdanubian population, however females migrated here to a greater extent. The sex-specific migration rate resulted that the anthropological traits of the local males persisted even through the Late Avar period, while the continuity of the females localised to Baranya-county.

During the Late Avar period new populations had arrived to Eastern-Transdanubia and occupied mostly the present territories of Tolna-and Fejér-counties. As far as Baranya-county is concerned, the Late Avar period population was formed on the basis of Romance, Germanic and Early Avar period population. The new inhabitants of Eastern-Transdanubia had biological relations with populations living in the Danube-Tisza Interfluve and along the Tisza. Since these regions cover a relatively large geographic area, further systematic comparative studies are necessary to decipher the origin of these populations. Considering that there were similarities between the locally formed Late Avar period populations of Eastern-Transdanubia and the new immigrants, their biological integration could happen rapidly. From a demographic point of view, it is not possible to establish a causal relationship between the new population and the onset of the Late Avar period. Therefore, the cultural transition could have rather been the result of a cultural integration process.

Keywords: Avar Period; Carpathian Basin; Population history; Craniometry.

\section{Bevezetés}

Az avarokkal 568-ban egy új, ázsiai eredetű népesség jelent meg a Kárpát-medencében. A medence egész területére kiterjedő birodalmuk, az Avar Kaganátus a kora középkori európai fejlődési iránytól eltérő, nomád jellegü államalakulat volt, amely a közel két és félszáz év során a térség jelentős politikai, katonai hatalmává vált (Pohl 2002). A kaganátus 
„nomád” jellege abban rejlett, hogy a területek biztosítását elsősorban az ott élő népesség leigázásával valósították meg, és a sztyeppei lovas életmódnak köszönhetően jelentősen nagyobb területet tudtak irányításuk alatt tartani (Pohl 1988).

Az avar honfoglalást megelözően a Dunántúlon a késő-antik, romanizált lakosság mellett (Bierbrauer 2004) germán eredetü ,,autochton” népességekkel számolhatunk (Kiss 1992). A térség megszállás előtti kulturális diverzitása, kapcsolatrendszere az avar korszak első periódusában is fennmaradt (Vida 2008). A korai leletanyagban tapasztalt diverzitás a közép avar kor végére (670/680-8. század eleje) fokozatosan eltűnt, majd az egész Kárpátmedence területén egységes anyagi kultúra alakult ki, jelezve ezzel a késő avar kor kezdetét (Vida 2003). A kulturális változások tükrében felmerül, hogy a kora avar kori heterogén kultúra hordozóiban vajon az avar kort megelöző antik és germán időszak továbbélö népességeit láthatjuk? Mi történt ezekkel a csoportokkal az avar kor során, hogyan éltek együtt/keveredtek-e az autochton csoportok az új sztyeppei eredetü bevándorlókkal? A késő avar kor régészeti jelensége mögött kulturális integráció vagy új népességek megtelepedése állhatott?

\section{Célkitüzések}

A Kelet-Dunántúl esetében az ,autochton” (5. századi késő antik, 5-6. századi germán) és az avar kori népesség közötti kapcsolat tükrében az alábbi kérdésekre kerestem a választ:

- A késő antik és germán eredetü férfiak és nők milyen arányban éltek tovább a KeletDunántúl kora avar kori népességében?

- A közép avar korig tartó kulturális heterogenitás vajon az „,autochton” lakosság tovább élésének következménye?

- Az avar kort megelőzően a Kelet-Dunántúlon élt lakosság kontinuitása kimutathatóe a kora avar kor után a késő avar kori népességekben is?

- Vajon a germán és késő antik régészeti jellegek eltünése az „autochton” lakosság eltünésének/eltelepítésének eredménye vagy a kulturális integrációé?

- A Kelet-Dunántúl avar kori népességével kapcsolatban a következő kérdésekre próbáltam választ adni:

- Milyen kapcsolat lehetett a Kelet-Dunántúl kora avar kori népessége és a Kárpátmedence kortárs populációi között.

- Hogyan viszonyul a Kelet-Dunántúl késő avar kori népessége embertani szempontból a Kárpát-medencei térség kortárs népességeihez?

- Embertani jellegeit tekintve megegyezik-e a Kelet-Dunántúl késő avar kori népessége a kora avar korival?

- Vajon a késő avar korban megjelenő új, egységes anyagi kultúra egy új népesség megjelenésének a következménye?

Emellett célul tüztem ki, hogy a kelet-dunántúli térségből minél több elérhető kisebb sorozatot, valamint a régió egyik legnagyobb avar kori temetője, Kölked-Feketekapu embertani leletanyagát is megvizsgáljam, ezzel is bővítve az összehasonlításba bevonható szériák számát.

\section{Vizsgált anyag és alkalmazott módszerek}

A Kelet-Dunántúl avar kori népességei közül a disszertáció anyagában az alábbi sorozatok embertani anyaga szerepelt: Alsónyék-Elkerülö 3. lh, Dunaföldvár-Barota dülö, Kölked-Feketekapu A, Kölked-Feketekapu B. A kelet-dunántúli avar kori népességtörténet 
teljesebb megismeréséhez az összehasonlító adatsor bővítésére is szükség volt, mivel a Kárpát-medence számos térségből csak kevés antropológiai adattal rendelkezünk. Ezért olyan régiók embertani anyagát is vizsgáltam, amelyek korabeli népességéröl kevés irodalmi adat ismert. Ezek az alábbiak: Északkelet-Magyarország: Apc-Berekalja, Bélapátfalva-Sass tag, Kál-Csörszkavics bánya, Tarnaméra-Urak-dülö, VisontaNagycsapás; Tiszántúl: Rákóczifalva -Bagiföldek 5. lh, Rákóczifalva-Bagiföldek 8. lh, Rákóczifalva-Bagiföldek 8/A. lh.

A morfológiai nem meghatározásához, a biológiai életkor becsléséhez, valamint a koponyák metrikus elemzéséhez a nemzetközi és hazai szakirodalomban általánosan elfogadott módszereket használtam fel (Martin és Saller 1957, Pap és mtsai 2009).

Az összehasonlító kraniometriai elemzés során a férfiak és nők koponyájának 10 méretet vettem figyelembe (M1, M8, M9, M17, M45, M48, M51, M52, M54, M55). A koponyaméreteken Darroch-Mosimann (1985) transzformációt végeztem el. A kraniometriai összehasonlító vizsgálatokat területi és időrendi szempontból több összeállításban végeztem el. A terület szempontjából Kölked-Feketekapu, Baranya-megye, illetve az egész Kelet-Dunántúl tekintetében vizsgáltam a lehetséges népességváltozásokat és embertani kapcsolatokat. Az időrend szempontjából diakron (különböző korszakok népességei között) és szinkron megközelítéssel (egyazon korszak népességei között) végeztem el az összehasonlító vizsgálatokat. Valamennyi elemzést a férfiakra és a nőkre külön is elvégeztem.

Az összehasonlított csoportok koponyaformájának variabilitását fökomponens-analízis (PCA) és szórásdiagram segítségével szemléltettem. A populációk közötti hasonlóság megítéléséhez különböző heritabilitási értéken alapuló R-mátrix analízist végeztem, amelyből a minta méretére korrigált Fst értéket számoltam ki (Williams-Blangero és Blangero 1989, Relethford és Blangero 1990). A népességek közötti biológiai kapcsolat erősségének kifejezéséhez szintén az R-mátrix elemzésből számított mind2 és d2 távolságokat, valamint a Mahalanobis távolságot vettem alapul. A különbségek és hasonlóságok grafikus megjelenítéséhez az R-mátrix elemeiből többdimenziós skálázást végeztem majd az első két fökoordináta mentén ábrázoltam az adatokat. Ezekhez a számításokhoz az RMET 5.0 és a PAST 3 programokat használtam. Az elemzett csoportoktól különböző forrásból érkező génáramlás mértékét a Relethford-Blangeroelemzés segítségével becsültem meg (Relethford és Blangero 1990). A földrajzi és a biológiai távolság közötti kapcsolat erősségét Mantel-teszt segítségével ellenőriztem, amihez a PASSaGE 1.1 programot használtam. Minden statisztikai próba és biológiai távolságérték esetében $\alpha=0.05$ szinten tekintettem szignifikánsnak az eredményeket.

\section{Következtetések}

A Kelet-Dunántúl avar kori népességváltozásainak vizsgálatában a fő célkitüzés az egymást követő korszakok és az egyes időszakok kortárs népességei között kapcsolatok rekonstrukciója volt. Az eredmények egy része korábbi embertani hipotéziseket támasztott alá és egészített ki, emellett új eredményekkel is sikerült hozzájárulni az avar kor embertani kutatásához. Ezek között vannak általánosítható megfigyelések az egyes vizsgált lelőhelyekre, a teljes kelet-dunántúli térségre és az egész avar korszakra vonatkozóan is.

Éry (1982) feltételezte, hogy a kelet-dunántúli régió avar kori népességébe beolvadt a késő antik lakosság. Kutatásaim eredményei megerősítik ezt a felvetést, illetve kiegészítik azt. 
- A késő antik időszakbeli népesség férfi csoportjai az egész kelet-dunántúli régióban megélték a kora avar kort, embertani jellegzetességeik még a késő avar korban is kimutathatók.

- A késő antik kori népesség női csoportjai kisebb arányban élték meg a kora avar kort, továbbélésük elsősorban Kölked-Feketekapu „A” kora avar kori populációjában mutatható ki. A késő avar korra még inkább csökkent a kontinuitás mértéke, azonban Kölked-Feketekapu „A” és „B” népességében kraniometriai jellegeik továbbra is jelentősek voltak.

Az összehasonlító vizsgálatokban az összevetésre 5. századi germán és langobárd kori embertani szériákat is felhasználtam. Bár elemszámuk nem volt olyan jelentős, mint a késő római kori népességé, kontinuitásukra vonatkozóan bizonyos következtetések levonhatók:

- Az 5. századi késő antik és a germán népességek között kimutatható biológiai kapcsolat. Ez alól kivételt képeztek az 5. századi germán és a langobárd kori népesség női csoportjai, ugyanis közöttük nagyobb mértékü volt a különbség.

- A Kelet-Dunántúlon a kora avar kori Kölked-Feketekapu „A” és CsákberényOrondpuszta esetében az 5. századi germán és langobárd kori férfiak tovább élése igazolható. A késő avar korban Kölked-Feketekapu „A” népesség férfi csoportjának esetében szintén kimutatható a langobárd és germán embertani hatás.

- A kelet-dunántúli kora avar kori nők között kimutatható az 5. századi germán és a langobárd kori nők továbbélése, ugyanakkor a késő avar korszakig tartó kontinuitásuk már csak a kölkedi lelőhelyre (leginkább az „A” temetőrészre) lokalizálódik.

A disszertáció új eredménye Kölked-Feketekapu „A” és „,B” lelőhelyein feltárt temető 970 egyénének az embertani eredménysora. A széria kraniometriai elemzésének köszönhetően a lelöhely avar kori történetével kapcsolatban az alábbi következtetések vonhatók le:

- A korai avar korban a két lelöhelyrész férfi csoportjai jelentősen különböznek egymástól. Az „A” temetőbe temetett férfiak az avar kort megelőző (késő római, 5. századi germán és langobárd kori) népesség leszármazottainak tekinthetők.

- A „B” lelőhelyen temetkező kora avar kori férfiak és a vajdasági kora avar kori csoportok között biológiai kapcsolat állhatott fenn. Ez okozhatta a szignifikáns eltérést a két kölkedi temető korai szakaszai között.

- A két lelöhelyrész kora avar kori női egyénei között nincs jelentős eltérés. KölkedFeketekapu „B” széria női csoportja jobban hasonlít a kortárs Kárpát-medencei nőkhöz, de az „A” temetörészbe temetett nők sem térnek el tőlük szignifikánsan. A kora avar korban más térségből a mai Kölked területére érkezett nők azonos arányban telepedhettek meg az „A” és „B” lelőhelyek között. Az újonnan érkezett kora avar kori nők egy része a férfiakhoz hasonlóan a vajdasági kora avar kori csoportokhoz köthető. - Kölked-Feketekapu „A” és „B” késő avar kori népességének többsége az „A” temetőrész korai fázisából származtatható.

A kelet-dunántúli régió kora avar kori népességére vonatkozó új eredményekből az alábbi következtetések vonhatók le:

- A térség kora avar kori populációira jellemző kulturális heterogenitás mellett az itt élő népesség embertani arculata is sokszínű volt. A 6-7. századi lakosság embertan arculatának kialakításában döntően a késő római kori, az 5 . századi germán és a langobárd kori népességek hatása érvényesült, kisebb mértékben a kora avar kori csoportoké. 
- A férfiak biológiai szempontból elszigetelődtek a Kárpát-medence kortárs avar kori népességeitől. A nők azonban nagyobb arányban más területekről érkeztek a KeletDunántúlra.

- A kelet-dunántúli népességnek elsősorban a vajdasági kora avar kori populációkkal lehetett biológiai kapcsolata.

A kelet-dunántúli régió késő avar kori népességének kialakulásával kapcsolatban az alábbiak fogalmazhatók meg:

- Az avar kort megelőző népességek férfi csoportjainak embertani jellege változó arányban oszlik el a késő avar kori populációiban. Ezzel szemben a nők tovább élése területileg „,szigetszerü” és szinte kizárólag (a mai) Baranya-megyére koncentrálódik.

- A kelet-dunántúli régió késő avar kori népessége nem tekinthető teljes egészében a kora avar kori csoportok közvetlen folytatásának. A térség történetében új embertani komponensek jelentek meg, tehát részben változott a népesség a kora és késő avar kor között. A bevándorolt populációk a Duna-Tisza közéről és a Tisza-melléki területekröl érkezhettek.

- A késő avar kori népességváltozás nem egyenlő arányban érintette a Kelet-Dunántúl különbözö területeit. A baranyai régióban a kora avar kori lakosság nagyobb arányban élte meg a késő avar kort, mint a Kelet-Dunántúl más területein.

- A késő avar kort kísérő kulturális egységesedést embertani homogenizáció kísérte, ugyanakkor jelentős különbségek is kimutathatók a térségbe érkezett új népességek miatt.

- A Kelet-Dunántúl késő avar kori lakosságában új embertani elemnek számít Dunaszentgyörgy-Tengelic, Elöszállás-Bajcsihegy, Pécs-Boros Sámuel utca és Szekszárd-Palánk lelőhelyek népességeinek számottevő része, amely mindkét nem esetében egyértelmüen kimutatható.

A Kelet-Dunántúlon a késő avar korban megjelent új népesség eredetének megfejtéséhez ezeket a sorozatokat összevetettem a Kárpát-medence más térségeinek kortárs populációival.

- Dunaszentgyörgy-Tengelic népességének legközelebbi párhuzamai a Duna-Tisza közére, Homokmégy-Halom, Kecel, Üllő I. és II. lelőhelyekre mutattak. Ezeknek a népességeknek eddig nem volt ismert dunántúli analógiája.

- Elöszállás-Bajcsihegy népességének férfi csoportja szintén Duna-Tisza közi szériákhoz hasonlít, elsősorban a Kiskőrös-Város alatt és a Jánoshida-Tótkérpuszta lelőhelyeken feltárt embertani anyaghoz. A nők esetében további analógiaként a tiszántúli Szentes-Kaján is felmerül, tehát nagyobb kiterjedésü régióval mutatnak embertani kapcsolatokat. Ezeknek a népességeknek a kapcsolatait már feltételezték korábban is (Fóthi 1984).

- A Pécs-Boros Sámuel utca lelöhelyen feltárt embertani széria férfi csoportjának legközelebbi analógiája a nyugat-dunántúli Kaposvár 61. út 26. lelőhely népessége. Ez a két lelőhely lazábban kapcsolódik az előszállási férfi mintához, de a Duna-Tisza köziekhez már nem. Ez alapján elképzelhető, hogy ezeket a népességeket a Duna bal partjáról a Kelet-Dunántúlra áttelepült és keveredett, az előszállásihoz hasonló férfi csoport alkotta. Pécs-Boros Sámuel utca lelőhely női csoportja nem tér el jelentősen a Kelet-Dunántúl baranyai régiójának késő avar kori nőitöl. Ezért a pécsi lelőhely esetében a férfiak és nők eltérő eredetével számolhatunk.

- Szekszárd-Palánk esetében a férfiak és nök is Duna-Tisza közi és Tisza-mentén élt népességekkel mutattak kapcsolatot. A férfiak közvetlen analógiájaként Szeged- 
Fehértó „A”, a nők esetében Tiszaderzs, Üllő II. és Homokmégy-Halom lelőhelyei merülnek fel.

A Kelet-Dunántúl késő avar kori népesség helyben kialakult részére vonatkozó eredmények a következők:

- A Nyugat-Dunántúl délkeleti részének késő avar kori népessége a baranyai régió zömében helyben kialakult csoportjaitól (Kölked-Feketekapu „A” és „B”, valamint Szebény) származtatható. A jutasi széria alapján a Balatontól északra élő késő avar kori népességeknek is lehetettek szoros kapcsolatai a baranyai régióval.

- A Tiszántúl késő avar kori népességét biológiai kapcsolat füzte a KeletDunántúlhoz. Ebbe beletartoznak azok a kelet-dunántúli lelöhelyek népességei is, akik valószínüleg származási helyüknél fogva mutatnak hasonlóságot a Tiszántúllal, mint Előszállás-Bajcsihegy vagy Szekszárd-Palánk. Azonban a Kelet-Dunántúlon kialakult csoportok közül Kölked-Feketekapu „A” és „B” késő avar kori népességének férfi csoportja és Tiszaderzs között is szoros analógia mutatható ki.

A disszertáció eredményeiből közvetve a Kárpát-medence avar kori népességstruktúrájára vonatkozóan is levonhatók következtetések.

- A Kárpát-medence különböző régióinak kora avar kori népességei között szignifikáns különbségek voltak. Ezek az eltérések elsősorban etnikai, politikai alapúak lehettek, nem a földrajzi távolság okozta öket.

- Ahogy Éry Kinga felvetette (1982), a késő avar kori népesség embertani jellegei alapján a nagyobb földrajzi régióknak megfelelően elkülöníthetők regionális csoportok. Ebben a biológiai elkülönülésben azonban a földrajzi távolság okozta génáramlási korlátok már jelentős szerepet játszottak.

- Az Éry Kinga (1982) által kraniometriai jellegeik alapján elkülönített keletdunántúli régióba Csákberény-Orondpuszta, Előszállás-Bajcsihegy, Kékesd, Szebény és Szekszárd-Palánk népességei tartoztak. A disszertáció eredményei alapján a keletdunántúli régió avar kori népességei két részre oszthatók:

1. Azokra a népességekre, amelyek elsősorban az avar kort megelőző lakosság és a kora avar kori populáció keveredéséből alakultak ki a térségben. Ezt a csoportot az alábbi sorozatok képviselik: Csákberény-Orondpuszta, Kékesd, Kölked-Feketekapu „A” és „B” és Szebény.

2. Azokra a népességekre, amelyekben jelentős mértékü a fent elkülönített 1 . keletdunántúli csoporttól idegen embertani komponens megléte. Ezt a csoportot az alábbi sorozatok képviselik: Dunaszentgyörgy-Tengelic, Előszállás-Bajcsihegy, Pécs-BorosSámuel utca, Szekszárd-Palánk.

- A Kárpát-medence kora és késő avar kori népességének férfi csoportjai között is nagyobb az elkülönülés mértéke, mint a nők esetében. Ennek az oka feltehetően az avar kori társadalom virilokális (a férj helyén való együttélés) berendezkedésében kereshető.

\section{Felhasznált irodalom}

Bierbrauer, V. (2004): A Keszthely-kultúra és a késő római továbbélés kérdése Pannoniában (Kr. u. 5-8. sz.). Archaeologiai Értesitö, 129: 67-82. DOI: https://doi.org/10.1556/ArchErt.129.2004.1-2.3

Darroch, J.N., Mosimann, J.E. (1985): Canonical and principal components of shape. Biometrika 72(2): 241-252. DOI: https://doi.org/10.2307/2336077

Éry, K. (1982): Újabb összehasonlító statisztikai vizsgálatok a Kárpát-medence 6-12. századi népességeinek embertanához. VMMK, 16: 35-86.

Fóthi, E. (1984). A Kárpát-medence avar korának összehasonlító embertani vizsgálata. MFMÉ, 85 : 483-501. 
Kiss, A. (1992): Germanen im awarenzeitlichen Karpatenbecken. Awarenforschungen, 1: 35-134. Martin, R., Saller, K. (1957): Lehrbuch der Anthropologie. Bd 1. Gustav Fischer Verlag, Stuttgart.

Pap, I., Fóthi, E., Józsa, L., Bernert, Zs., Hajdu, T., Molnár, E., Bereczki, Zs., Lovász, G., Pálfi, Gy. (2009): Történeti embertani protokoll - A régészeti feltárások embertani anyagainak kezelésére, alapszintü feldolgozására és elsődleges tudományos vizsgálatára. Anthropologiai Közlemények, 50: $105-123$.

Pohl, W. (1998): Gepiden. Historisches. In: Hoops, J (Ed.) Reallexikon der Germanischen Altertumskunde 11.pp. 118-131.

Pohl, W. (2002): Die Awaren: ein Steppenvolk im Mitteleuropa. Beck V., München. pp. 567-822.

Relethford, J.H., Blangero, J. (1990): Detection of differential gene flow from patterns of quantitative variation. Human Biology, 62: 5-25.

Vida, T. (2003): A korai és közép avar kor. In: Visy, Zs. (Szerk.) Magyar Régészet az ezredfordulón. Nemzeti Kulturális Örökség Minisztériuma, Teleki László Alapítvány, Budapest. pp. 302-308.

Vida, T. (2008): Conflict and coexistence: the local population of the Carpathian Basin under Avar rule (sixth to seventh century). In: Curta, F. (Ed.) The other Europe in the Middle Ages. Brill, Leiden - Boston. pp. 13-46.

Williams-Blangero, S., Blangero, J. (1989): Anthropometric variation and the genetic structure of the Jirels of Nepal. Human Biology, 61: 1-12.

\section{A doktori értekezéshez kapcsolódó, referált folyóiratokban megjelent tanulmányok}

Szeniczey, T., Bernert, Zs., Czuppon, T., Marcsik, A., Szabó, G., Hajdu, T. (2013): Embertani adatok Tolna megye avar korához. Anthropologiai Közlemények, 54: 59-76.

Wolff, K., Bernert, Zs., Balassa, T., Szeniczey, T., Kiss, K. Cs., Hajdu, T. (2014): Two suture craniosynostosis a presentation that need to be noted. Journal of Craniofacial Surgery, 25(2): 714-715. DOI: https://doi.org/10.1097/SCS.0000000000000473

Mathieson, I., Alpaslan-Roodenberg, S., Posth, C., Szécsényi-Nagy, A., Rohland, N., Mallick, S., Olalde, I., Broomandkhoshbacht, N., Candilio, F., Cheronet, O., Fernandes, D., Ferry, M., Gamarra, B., Fortes, G.G., Haak, W., Harney, E., Jones, E., Keating, D., Krause-Kyora, B., Kucukkalipci, I., Michel, M., Mittnik, A., Nägele, K., Novak, M., Oppenheimer, J., Patterson, N., Pfrengle, S., Sirak, K., Stewardson, K., Vai, S., Alexandrov, S., Alt, K.W., Andreescu, R., Antonović, D., Ash, A., Atanassova, N., Bacvarov, K., Gusztáv, M.B., Bocherens, H., Bolus, M., Boroneanţ, A., Boyadzhiev, Y., Budnik, A., Burmaz, J., Chohadzhiev, S., Conard, N.J., Cottiaux, R., Čuka, M., Cupillard, C., Drucker, D.G., Elenski, N., Francken, M., Galabova, B., Ganetsovski, G., Gély, B., Hajdu, T., Handzhyiska, V., Harvati, K., Higham, T., Iliev, S., Janković, I., Karavanić, I., Kennett, D.J., Komšo, D., Kozak, A., Labuda, D., Lari, M., Lazar, C., Leppek, M., Leshtakov, K., Vetro, D.L., Los, D., Lozanov, I., Malina, M., Martini, F., McSweeney, K., Meller, H., Menđušić, M., Mirea, P., Moiseyev, V., Petrova, V., Price, T.D., Simalcsik, A., Sineo, L., Šlaus, M., Slavchev, V., Stanev, P., Starović, A., Szeniczey, T., Talamo, S., Teschler-Nicola, M., Thevenet, C., Valchev, I., Valentin, F., Vasilyev, S., Veljanovska, F., Venelinova, S., Veselovskaya, E., Viola, B., Virag, C., Zaninović, J., Zäuner, S., Stockhammer, P.W., Catalano, G., Krauß, R., Caramelli, D., Zarina, G., Gaydarska, B., Lillie, M., Nikitin, A.G., Potekhina, I., Papathanasiou, A., Borić, D., Bonsall, C., Krause, J., Pinhasi, R., Reich, D. (2018): The genomic history of southeastern Europe. Nature, 555(7695): 197-203. DOI: https://doi.org/10.1038/nature25778

Olalde, I., Brace, S., Allentoft, M.E., Armit, I., Kristiansen, K., Booth, T., Rohland, N., Mallick, S., Szécsényi-Nagy, A., Mittnik, A., Altena, E., Lipson, M., Lazaridis, I., Harper, T.K., Patterson, N., Broomandkhoshbacht, N., Diekmann, Y., Faltyskova, Z., Fernandes, D., Ferry, M., Harney, E., de Knijff, P., Michel, M., Oppenheimer, J., Stewardson, K., Barclay, A., Alt, K.W., Liesau, C., Ríos, P., Blasco, C., Miguel, J.V., García, R.M., Fernández, A.A., Bánffy, E., Bernabò-Brea, M., Billoin, D., Bonsall, C., Bonsall, L., Allen, T., Büster, L., Carver, S., Navarro. L,C,, Craig, O.E., Cook, G.T., Cunliffe, B., Denaire, A., Dinwiddy, K.E., Dodwell, N., Ernée, M., Evans, C., Kuchařík, M., Farré, J.F., Fowler, C., Gazenbeek, M., Pena, R.G., Haber-Uriarte, M., Haduch, 
E., Hey, G., Jowett, N., Knowles, T., Massy, K., Pfrengle, S., Lefranc, P., Lemercier, O., Lefebvre, A., Martínez, C.H., Olmo, V.G., Ramírez, A.B., Maurandi, J.L., Majó, T., McKinley, J.I., McSweeney, K., Mende, B.G., Modi, A., Kulcsár, G., Kiss, V., Czene, A., Patay, R., Endrődi, A., Köhler, K., Hajdu, T., Szeniczey, T., Dani, J., Bernert, Z., Hoole, M., Cheronet, O., Keating, D., Velemínský, P., Dobeš, M., Candilio, F., Brown, F., Fernández, R.F., Herrero-Corral, A.M., Tusa, S., Carnieri, E., Lentini, L., Valenti, A., Zanini, A., Waddington, C., Delibes, G., GuerraDoce, E., Neil, B., Brittain, M., Luke, M., Mortimer, R., Desideri, J., Besse, M., Brücken, G., Furmanek, M., Hałuszko, A., Mackiewicz, M., Rapiński, A., Leach, S., Soriano, I., Lillios, K.T., Cardoso, J.L., Pearson, M.P., Włodarczak, P., Price, T.D., Prieto, P., Rey, P.J., Risch, R., Guerra, M.A.R., Schmitt, A., Serralongue, J., Silva, A.M., Smrčka, V., Vergnaud, L., Zilhão, J., Caramelli, D., Higham, T., Thomas, M.G., Kennett, D.J., Fokkens, H., Heyd, V., Sheridan, A., Sjögren, K.G., Stockhammer. P.W., Krause, J., Pinhasi, R., Haak, W., Barnes, I., Lalueza-Fox, C., Reich, D. (2018): The Beaker phenomenon and the genomic transformation of northwest Europe. Nature, 555(7695): 190-196. DOI: https://doi.org/10.1038/nature25738

Szeniczey, T., Marcsik, A., Ács, Zs., Balassa, T., Bernert, Z., Bakó, K., Czuppon, T., Endrődi, A., Évinger, S.,Farkas, Z.; Hlavenková, L.; Hoppál, K., Kálmán, Kiss C., Kiss, K., Kocsis, K., Kovács, L.O., Kovács, P.F., Köhler, K., Költő, L., Kővári, I., László, O, Lovász, G., Lovranits, J., Lukács, J., Masek, Z., Merczi, M., Molnár, E., Németh, C.E., Ódor, J.G., Paja, L., Pap, I., Patay, R.; Rácz, I., Rácz, Z., Ritoók, Á., Szenthe, G., Szilas, G., Szőke, B.M., Tóth, Z., Vida, T., Wolff, K., Finnegan, M., Hajdu, T. (2019): Hyperostosis frontalis interna in ancient populations from the Carpathian Basin - a possible relationship between lifestyle and risk of development. International Journal of Paleopathology, 24: 108-118. DOI: https://doi.org/10.1016/j.ijpp.2018.10.003

\section{A doktori értekezéshez kapcsolódó további publikációk}

Szeniczey, T., Bernert, Zs., Czuppon, T., Marcsik, A., Hajdu, T. (2013): Results of the anthropological investigation from the Avar Period cemeteries of Dunaszentgyörgy-Proletárdülö and Dunaszentgyörgy 6. út 119. VIII. Kárpát-medencei Biológiai Szimpózium. I. Fenntartható fejlödés a Kárpát-medencében. Előadáskötet. pp. 70-71.

Szeniczey, T., Bernert, Zs., Czuppon, T., Marcsik, A., Szabó, G., Czövek, A., Bakó, K., Hajdu, T. (2014): Paleopathological investigation of two cemeteries from the 8th-9th century AD (Late Avar Period) in Hungary. Coins - Conference of Natural and Life Sciences. Abstracts. 67-68.

Szeniczey, T., Bakó, K., Bernert, Zs., Kovacsóczy, B., Marcsik, A., Ódor, J., Hajdu, T. (2014): Paleopathologicalinvestigations of East-Transdanubiancemeteriesin Hungary fromthe 7th to 8th centuries AD - the Avar Age. „Day of the Dead” - Recent Research in Human Osteoarchaeology. Programme and Abstracts, p. 52.

Szeniczey, T., Rácz, Zs., Mácsai, V., Schmid, M.E., Donoghue, H.D., Mosaku, O., Jamil, S., Sirak, K., Pinhasi, R., Marcsik, A., Hajdu, T. (2016): Multidisciplinary examination of an Avar Age population from the Middle Tisza region. IUAES Inter Congress. World anthropologies and privatization of knowledge: engaging anthropology in public. Abstract book. p. 128

Szeniczey, T., Marcsik, A., Sirak, K., Fernandez, D., Pinhasi, R., Hajdu, T. (2016): Possible cases of tuberculosis from Kölked-Feketekapu „A” Early Avar Period cemetery (Eastern Transdanubia, Hungary). 20th Congress of the European Anthropological Association. European Anthropology in a Changing World: From Culture to Global Biology. Abstract book, p. 27.

Szeniczey, T. (2016): Kál-Csörszkavics-bánya lelőhelyen feltárt avar kori emberi maradványok embertani vizsgálata. Agria, 49: 243-252.

Szeniczey, T., Rácz, Zs., Marcsik, A., Hajdu, T. (2017): Pusztataskony-Ledence 1. és 2. lelöhely 56. századi embertani leleteinek antropológiai vizsgálata. Tisicum, 25: 309-322.

Szeniczey, T., Bernert, Zs., Bakó, K., Kovacsóczy, B., Marcsik A., Ódor, J. G., Hajdu T. (2017): Alsónyék-elkerülő 2. lelőhely és Dunaföldvár-Barota-dülő avar kori népességének biológiai rekonstrukciója. In: Türk, A., Balogh, Cs., Major, B. (Szerk.) Hadak útján XXIV. A népvándorláskor fiatal kutatóinak XXIV. konferenciája 2. Archaeolingua, Budapest. pp. $103-123$ 
Szeniczey, T., Hajdu, T., Marcsik, A. (2018): Gepidák az Alföldön a történeti embertani adatok alapján. Irodalmi ismertetés. In: Korom, A. (Szerk.) Relationes Rerum Régészeti tanulmányok Nagy Margit tiszteletére. Studia ad Archaeologiam Pazmaniensia, 10: 447-458.

Szeniczey, T., Marcsik, A., Hajdu, T. (2018): The physical anthropological analysis of grave A-108 of the Kölked-Feketekapu Cemetery. Appendix. In: Vida, T. (Szerk.) Being Avar! A Case Study for Changes in the Social Display of Identity in the Early Avar Period. 419-431. In: Drauschke, J., Kühtreiber, E., Kieslinger, K. Kühltreiber, T., Scharrer-Liska, G., Vida T. (Eds.): Lebenswelten zwischen Archäologie und Geschichte. Festschrift für Falko Daim zu Seinem 65. Geburtstag. Verlag des Römisch-Germanischen Zentralmuseums, pp. 432-436.

Szeniczey, T., Hajdu, T., Marcsik, A. (2019): Skeletal remains of the Gepid period in the Great Hungarian Plain. Literature review. In: Gál, Sz.S. (Ed.) The talking dead (2). Past and present of biological anthropology. The heritage of Török Aurél's Oeuvre. Bibliotheca Musei Marisiensis - Series Archaeologica 17. Mega Publishing House, Targu Mures.

Levelezési cím: $\quad$ Szeniczey Tamás

Mailing address: Embertani Tanszék

Eötvös Loránd Tudományegyetem

Pázmány P. s. 1/c.

H-1117 Budapest

Hungary

szeniczey.t@gmail.com 
